\title{
INTEGRATING ABC AND EVA TO EVALUATE INVESTMENT DECISIONS
}

\author{
N. Chiadamrong \\ Industrial Engineering Program \\ Sirindhorn International Institute of Technology \\ Thammasat University, Pathunthani, 12121, Thailand \\ E-mail: navee@siit.tu.ac.th
}

Received 23 May 2002, Accepted 11 February 2003

\begin{abstract}
The significance of investment is transparent in the world of competitive business. Traditional costing systems in which their emphasizes are for short term savings rather than long term benefits have shown some lacking in providing accurate and reliable cost data for the investment decisions. Activity-based Costing (ABC), which is developed to satisfy some of the weaknesses of the traditional costing systems, can provide valuable insights into the operating processes and come up with more accurate cost data. In this paper, $\mathrm{ABC}$ is used to provide significant information for investment decisions. Although, the $\mathrm{ABC}$ method provides accurate operating product costs, it does not identify which products are economic valued added creators and so contribute to companies' wealth. This drawback can be overcome by applying Economic Value Added (EVA). The adoption of ABC and EVA can represent a considerable change in the managerial thinking and to corporate strategies and business performance.
\end{abstract}

\section{INTRODUCTION AND PROBLEM BACKGROUND}

Activity-based Costing ( $\mathrm{ABC}$ ) is one of the latest models in cost accounting. It is primarily aimed at enlarging the range of cost drivers in product costing in order to broaden the scope of activities for which the cost can be causally linked to products. In fact, it is based on a simple idea: in an enterprise, overhead (or operating) expenses are generated by activities needed in manufacturing and business processes. Since activities consume overhead resources, and products (projects or processes) demand activities, the cost of products is related to the cost of resources. By design, $\mathrm{ABC}$ provides not only relatively accurate cost, but also information about the origin of the cost ${ }^{1}$. In other words, $\mathrm{ABC}$ makes overhead costs traceable. Since the objective of this paper is not to present how $\mathrm{ABC}$ works and the merits of implementing $\mathrm{ABC}$, these issues have been well discussed and can be found in many management literatures ${ }^{2-6}$.

The identification of cause-and-effect relationships between supporting activities and manufacturing characteristics (so called "cost drivers") opens up possibilities for activity-based justification. Unfortunately, there have been few attempts to integrate the more accurate product 
costing through using $\mathrm{ABC}$ with more reliable investment justification. One major reason is that $\mathrm{ABC}$ is typically used to apportion the indirect costs (typically fixed) between each product based on the amount of activities they consume while capital investments in terms of funds, cash, land and properties (which have no obvious activity in their nature) cannot use the traditional knowledge of $\mathrm{ABC}$ for its allocation. In other words, $\mathrm{ABC}$ ignores the cost of invested funds when measuring the economic consequences of these decisions. Integrating the cost of funds into $\mathrm{ABC}$ offers a means of tracing a company's costs, including the cost of invested funds, to the lowest level of its operations. This enables the economic cost of an activity's service as well as the cost of invested funds of the products to be measured thoroughly. In this paper, an attempt is then made to further apply the concepts and benefits of ABC into the investment justification. Non-activity capital investments (cost of invested funds) will also be driven by their drivers and allocated to each product. This makes it possible to extend the concept of $\mathrm{ABC}$ for the investment decision-making and valuation. It will provide an interesting outcome, showing an alternative to the traditional justification methods using Discounted Cash Flow (DCF) such as Net Present Value (NPV).

The use of NPV for investment decision-making and valuation is well entrenched in finance theory and practice. If used properly, NPV captures all of the elements of a project that affect the value of the company. The value of any project, and the amount of resources the company is willing to commit to it, is based on how much cash the project is expected to generate in the future, with the cash flows discounted at the rate of return that reflects the company's cost of capital. This cost of capital is, in turn, a function of the project's perceived riskiness, with highly risky projects requiring higher returns than less risky projects. In summary, the value of a capital investment is the expected cash flow discounted at a rate that reflects the riskiness of the cash flow. If the value is greater than the investment required, the project is said to have a positive Net Present Value (NPV). Positive NPV projects create value, while negative NPV projects destroy it.

The last few years have witnessed a tremendous growth in writing on Economic Value Added (EVA) in financial press, practitioner publications, and numerous unpublished working papers. These extensions, however, have also raised a number of concerns related to putting DCF theory into practice ${ }^{7}$. EVA, a registered trademark of Stern Stewart \& Company, has been implemented in numerous large companies to motivate managers to create shareholder value ${ }^{8}$. If the EVA is positive, the company creates shareholder wealth. Negative EVA indicates that shareholder wealth is destroyed. Company managers need a tool to help them manage both cost and capital. The primary purpose of this paper is to fill the drawback of using $A B C$ in justifying investment decisions by supplementing it with the EVA method. Two illustrative examples were constructed to demonstrate and highlight the benefits of such approach. The integrated $\mathrm{ABC}$ and EVA method will not only help managers in companies understand that the capital invested in their company is a precious resource that has to be used effectively but also provide a more comprehensive set of information for making planning and control decisions that can be used to maximize the company's economic income. 


\section{HOW DOES EVA WORK?}

Profitability is not sufficient to measure the company success performance. A company should be viewed as successful only if the return on its projects is better than the rate investors could expect to earn themselves (on a risk-adjusted basis) in the capital market. It therefore measures the dollar value of the company's return in excess of its cost of capital. EVA, like the earlier term, "residual income", measures the difference between the return on a company's project and the cost of that capital. EVA is similar to conventional accounting measures of profit but with an importance difference: EVA considers the cost of all capital. The net income figures reported in company income statements consider only the most visible type of capital cost, interest, while ignoring the cost of equity finance. One way to think of EVA is that it represents a company's net income, net of the cost of both debt and equity capital.

EVA is calculated as follows:

Net sales

\section{- Operating expenses}

= Operating profit

- $\underline{\text { Taxes }}$

= Net operating profit

- Capital charges

$=E V A$

Capital charges are based on the company's invested capital times the cost of that capital (what finance professionals call the capital asset pricing model or CAPM). The cost of capital computed under CAPM is composed of a risk free rate and a risk premium reflecting the relative risk of the company's stock. The risk free rate of the equity is approximated using the return of a long-term government bond. The risk premium is computed by multiplying the return for the market times the stock's beta coefficient. The cost of debt and equity is weighted by the proportion each provides to determine the company's cost of capital. The resulting opportunity rate of return is multiplied, times the book value of the company's assets and subtracted from net operating profits to determine EVA.

The cost of capital or the cost of invested funds is a necessary cost of producing a company' s products. The cost of invested funds may not require cash expenditures as do other resources, but the revenues earned by the company must cover the cost of capital to create economic value for its owners. Therefore, the cost of capital, like that of consumable resources, should be included in an activity's, product's, cash flow's and customer's cost. These may be accomplished by tracing company's assets to its support and production activities and computing the opportunity cost of the invested funds. A cost driver can then be used to trace capital cost from support and production activities to objects of interest. Finally, EVA is consistent with the discounted cash flow methods. Thus, evaluating a company's performance and that of its business units with economic income is congruent with the principles used to make investment decisions. 


\section{ILLUSTRATIVE EXAMPLES}

Two simple examples are illustrated to demonstrate advantages of integrating ABC with EVA. In the first example, the superiority of EVA can be demonstrated by considering two products. The first sells for $\$ 100$, has an $\mathrm{ABC}$ cost of $\$ 30$, but requires capital employed of $\$ 100$. The second product also sells for $\$ 100$ and has an $\mathrm{ABC}$ cost of $\$ 30$, but requires capital employed of $\$ 1,000$. If the cost of capital is $10 \%$, then the first product has a positive EVA (economic profit) of $\$ 60$ (100-30-100x10\%), where as the second has a negative economic profit of $\$ 30$ $(100-30-1000 \times 10 \%)$. The first product creates wealth, while the second destroys it. Yet both have the same $\$ 70 \mathrm{ABC}$ profit. This example highlights the two major advantages of the integration of $\mathrm{ABC}$ with EVA. First, the decision maker becomes sensitive to the economic return of products, customers, and channels, and second, it rewards the more efficient use of capital $^{9}$.

In the second example, a case study was developed to demonstrate benefits of integrating $\mathrm{ABC}$ with EVA over the traditional justification methods. A situation is assumed in a medium-sized company who is planning to produce three products (product 1-3). The company plans to initially invest $\$ 6,100,000$ as its net asset employed in the project. This initial outlay can be categorized as follows;

3.1. Fixed asset $=\$ 5,500,000$, which includes:

(i) Net property, plant and equipment $(\mathrm{PP} \& \mathrm{E})=\$ 5,000,000$ (depreciated $10 \%$ annually)

(ii) Other long-term assets $=\$ 500,000$ (no depreciation)

3.2. Working capital $=\$ 600,000$, which includes:

(i) Cash $=\$ 100,000$

(ii) Inventory $=\$ 500,000$

The project is estimated to generate the net operating profit of $\$ 550,000$ each year during the five years' studying period. This amount is contributed from $\$ 163,040$ of product 1 ( $\$ 315,000$ from cash saving - $\$ 151,960$ from depreciation cost), $\$ 244,901$ of product 2 ( $\$ 490,000$ from cash saving - $\$ 245,099$ from depreciation cost) and $\$ 142,059$ of product 3 ( $\$ 245,000$ from cash saving - \$102,941 from depreciation cost). This means that the company has estimated the equal amount of sales and operating expenses for every year. For simplicity, it is also assumed that no further investment capital and additional working capital are required. This is done to simplify the study and to keep the company's net asset employed the same for the whole studying period (expect the value of its fixed assets (PP\&E) which is depreciated 10\% annually). In reality, the company's financial status can change from year to year, depending on its per- 
formance during that year and whether further investment funds are raised. However, these can easily be taken into account in the study, if needed, by updating the invested funds of that year before allocating them to the activities and products.

Based on the above-mentioned information, one might be thinking of selling more on product 2 since it generates the highest profit. Later, the study will show that this amount of profit is misleading and does not reflect the true company's profit. It is also assumed that no tax is charged (tax rate $=0 \%$ ). However, again if needed, taxes can be easily incorporated in the process by deducting them from the operating profit before calculating the net operating profit. Table 1 can be constructed to show the Net Present Value of this project.

Table 1 : Net Present Value (x \$1,000)

\begin{tabular}{|c|c|c|c|c|c|c|c|}
\hline Year & 0 & 1 & 2 & 3 & 4 & 5 & NPV \\
\hline $\begin{array}{l}\text { 1. Net asset employed } \\
\text { 1.1 Working capital } \\
\text { - Cash } \\
\text { - Inventory } \\
\text { 1.2 Fixed asset } \\
\text { - PP\&E } \\
\text { - Other long-term } \\
\text { assets } \\
\text { 2. Net operating profit } \\
\text { 3. Depreciation* } \\
\text { 4. Remaining assets at } \\
\text { the end of the project } \\
\text { 4.1. Working capital } \\
\text { - Cash } \\
\text { - Inventory } \\
\text { 4.2. Fixed asset } \\
\text { - Salvage value } \\
\text { - Other long-term } \\
\text { assets }\end{array}$ & $\begin{array}{r}-100 \\
-500 \\
-5,000 \\
-500\end{array}$ & $\begin{array}{l}550 \\
500\end{array}$ & $\begin{array}{l}550 \\
500\end{array}$ & $\begin{array}{l}550 \\
500\end{array}$ & $\begin{array}{l}550 \\
500\end{array}$ & $\begin{array}{r}100 \\
500 \\
2,500 \\
500\end{array}$ & \\
\hline $\begin{array}{l}\text { Cash flow } \\
\text { Present value } \\
(\text { Cost of capital }=10 \%)\end{array}$ & $-6,100$ & 1,050 & 1,050 & 1,050 & 1,050 & 4,650 & 115.65 \\
\hline
\end{tabular}

*Depreciation is a non-cash flow and so does not enter in the NPV cash flow analysis.

The result reveals that the project has its Net Present Value of $\$ 115,650$ and with this positive value, it is suggested that the project is worth investing. However, only with this amount of information, it is a distorted impression of profitability as one might be misguided to sell more on product 2. Obviously, there is an obvious shortage of the information on which products (and by how much) make the most or worst contribution to the company's wealth. Thus, each product is required to be economically justified one by one in order to track down its sole contribution to the company's wealth. However, as we can see from Table 1, traditional discounted cash flows do not offer any procedure to apportion the big pool of net asset employed (invested funds) to each product. Whatever calculated from the cash flow is just the cash generated from the whole invested funds and cannot be specified to each individual product. 
To solve the problem, the integrated ABC-EVA method is used to allocate these company's assets to its support and production activities and finally to each product. For demonstration, four activities (purchasing and storage, manufacturing, administration and marketing \& sales) are identified as support and production activities by the company. The cost drivers for each capital usage to each activity and from each activity to each product are listed in Table 2 and Table 3.

Table 2 : Capital usage's drivers

\begin{tabular}{|c|c|c|c|c|}
\hline \multirow{2}{*}{ Invested funds } & \multicolumn{3}{|c|}{ Activity } & $\begin{array}{c}\text { Marketing } \\
\text { and Sales }\end{array}$ \\
\cline { 2 - 5 } & $\begin{array}{c}\text { Purchasing } \\
\text { and Storage }\end{array}$ & Manufacturing & 50 & 50 \\
\hline $\begin{array}{c}\text { Working capital } \\
- \text { Cash\# }\end{array}$ & 25 & 0 & 0 & 0 \\
- Inventory* & 50 & 20 & 30 & 20 \\
\hline Fixed asset & 20 & 100 & 50 & 50 \\
- PP\&E & 0 & 30 & & \\
- Other long- & & & & \\
term assets\% & & & \\
\hline
\end{tabular}

The followings are examples of driver usages. The same proportional amount is assumed to apply for the whole studying period.

\# Number of decisions made, which involve using cash

* Number of issued cycles

+ Area occupied (square meter)

$\%$ Assigned to the functions where it was managed (proportional time consumed)

Table 3 : Activity usage's drivers

\begin{tabular}{|c|c|c|c|}
\hline \multirow{2}{*}{ Activity } & \multicolumn{3}{|c|}{ Product } \\
\cline { 2 - 4 } & Product 1 & Product 2 & Product 3 \\
\hline Purchasing and Storage $^{*}$ & 10 & 20 & 10 \\
\hline Manufacturing* $^{*}$ & 10 & 30 & 10 \\
\hline Administration $^{+}$ & 30 & 10 & 5 \\
\hline Marketing \& Sales\% $^{*}$ & 20 & 20 & 20 \\
\hline
\end{tabular}

The followings are examples of driver usages. The same proportional amount is assumed to apply for the whole studying period.
\# Time consumed (hours)
* Machine hours (hours)
+ Managing time (hours)
\% Time and effort spent on selling (hours) 
Table 4 : Example of the capital charge in year $1(\times \$ 1,000)$

\begin{tabular}{|l|c|c|c|c|}
\hline \multirow{2}{*}{\multicolumn{1}{|c|}{ Activity }} & \multirow{2}{*}{ Capital charge } & \multicolumn{3}{c|}{ Product } \\
\cline { 3 - 5 } & & Product 1 & Product 2 & Product 3 \\
\hline Purchasing and Storage & 96.538 & 24.135 & 48.269 & 24.135 \\
\hline Manufacturing & 319.942 & 63.988 & 191.965 & 63.988 \\
\hline Administration & 111.465 & 74.31 & 24.77 & 12.385 \\
\hline Marketing \& Sales & 82.054 & 27.35 & 27.35 & 27.35 \\
\hline $\begin{array}{l}\text { Capital charge } \\
\text { (Cost of capital =10\%) }\end{array}$ & 610 & 189.783 & 292.354 & 127.857 \\
\hline
\end{tabular}

From the drivers shown in Table 3, we can allocate each year's capital charges to each product. For example, in year one with the company's cost of capital of $10 \%$, the company initially invested $\$ 100,000$ in cash (capital charge $=\$ 10,000), \$ 500,000$ in inventory (capital charge = $\$ 50,000$ ), $\$ 5,000,000$ in PP\&E (capital charge $=\$ 500,000$ ) and $\$ 500,000$ in other long-term assets (capital charge $=\$ 50,000$ ). These are summed up to the first year's capital charge of $\$ 610,000$, which needs to be allocated to the activities and finally to the products as shown in Table 4. The same procedure is applied to the remaining years but the book asset value of PP\&E will need to be depreciated by $10 \%$ before calculating its capital charge.

Table 5 : EVA of product $1(\times \$ 1,000)$

\begin{tabular}{|l|c|c|c|c|c|c|}
\hline \multicolumn{1}{|c|}{ Year } & $\mathbf{1}$ & $\mathbf{2}$ & $\mathbf{3}$ & $\mathbf{4}$ & $\mathbf{5}$ & EVA \\
\hline 1. Net operating profit & 163.04 & 163.04 & 163.04 & 163.04 & 163.04 & \\
2. Capital charge & -189.783 & -174.588 & -159.392 & -144.196 & -129 & \\
\hline Economic profit & -26.743 & -11.548 & 3.648 & 18.844 & 34.04 & \\
Present value & -24.312 & -9.543 & 2.741 & 12.87 & 21.135 & 2.891 \\
$($ Cost of capital =10\%) & & & & & & \\
\hline
\end{tabular}

Table 6 : EVA of product $2(\times \$ 1,000)$

\begin{tabular}{|l|c|c|c|c|c|c|}
\hline \multicolumn{1}{|c|}{ Year } & $\mathbf{1}$ & $\mathbf{2}$ & $\mathbf{3}$ & $\mathbf{4}$ & $\mathbf{5}$ & EVA \\
\hline 1. Net operating profit & 244.901 & 244.901 & 244.901 & 244.901 & 244.901 & \\
2. Capital charge & -292.354 & -267.845 & -243.336 & -218.827 & -194.316 & \\
\hline Economic profit & -47.453 & -22.944 & 1.565 & 26.074 & 50.585 & \\
Present value & -43.14 & -18.961 & 1.176 & 17.809 & 31.408 & -11.708 \\
$($ Cost of capital =10\%) & & & & & & \\
\hline
\end{tabular}

Table 7 : EVA of product $3(\times \$ 1,000)$

\begin{tabular}{|l|c|c|c|c|c|c|}
\hline \multicolumn{1}{|c|}{ Year } & $\mathbf{1}$ & $\mathbf{2}$ & $\mathbf{3}$ & $\mathbf{4}$ & $\mathbf{5}$ & EVA \\
\hline 1. Net operating profit & 142.059 & 142.059 & 142.059 & 142.059 & 142.059 & \\
2. Capital charge & -127.857 & -117.565 & -243.336 & -96.977 & -86.682 & \\
\hline Economic profit & 14.202 & 24.494 & 34.788 & 45.082 & 55.377 & \\
Present value & 12.911 & 20.242 & 26.136 & 30.791 & 34.384 & 124.464 \\
$($ Cost of capital =10\%) & & & & & & \\
\hline
\end{tabular}


Analysis of the company's present value of economic profit and that of individual products in Table 5-7 provide managers with insights into where wealth is created and destroyed in the company's operations. This information may be used to guide future production decisions to enhance economic income. Prior analysis of individual products has suggested the product 2 offers the highest profit and the project is worth investing with the positive NPV of $\$ 115,650$. With the integrated method, the identical result can also be obtained as the project as a whole can still offer the present value of EVA of $\$ 115,650$. Thus, results from the method will not make the investment decision to change (especially, if more than one project are economically compared). However, the method can provide deeper insights into the economic of the company's operation processes. That is, it makes the cost of consumable and capital resources transparent with the respect to how they are used by support and production activities and how an activity's services are used in a product's production.

With this analysis, product 2 has now become the major loss and, as a result, should not be invested or needs major revision to stay in the market. If its price or cost cannot be adjusted to earn a breakeven EVA, the company may need to consider outsourcing or deleting it from the company's production line. Product 1 (which was previously considered as profitable) is also contributing only little to the company's wealth. However, product 3 (which was previously considered as offering the lowest profit) is, in fact, the best economic profit contributor and contributes most to the company's wealth. Now the company must consider how the resource consumed by product 2 or perhaps including product 1 may be used to produce more profitable products. In addition, management may need to reconsider its attitude towards product 3, which appears to be more attractive under the integrated $\mathrm{ABC}$ and EVA system. For example, management may wish to increase marketing efforts for product 3 in which the effort in marketing and sales has been equally spent to each product under the current practice.

As mentioned earlier, the presented case studies are intended to illustrate the proposed methodology and highlight benefits obtained from such an integrated approach. Thus, the cases have been simplified to incorporate only important aspects, ignoring some financial details and possible variations in issuing incomes and expenses during the studying period. However, the similar concept can definitely be applied in more complicated situations while obtaining the same insights and wealth of information.

\section{CONCLUSION}

In this paper, an attempt has been made to study the issues of the integrated ABC and EVA in manufacturing. Some case studies are presented to illustrate the benefits of such integration. The integrated system distinguishes two different activity costs: operating and capital charge. Operating costs mirror resource consumption in a company, while capital charges describe the company's capital investment cost. In addition, the application of $\mathrm{ABC}$ would lead to more accurate cost data and how the invested funds are allocated to products while EVA can provide a valuable measure of wealth creation and can be used to help align managerial decision making with company preferences. The capital charge added to activities and traced to the products attempts to account for the capital use and helps management understand the capital cost asso- 
ciated with the manufacturing processes. However, ABC and EVA must be used in a conjunction so that they can provide a complete picture of performance.

Management can obtain distorted impression of profitability if they look only at profit after taxes in the traditional sense as opposed to economic profit as calculated in the integrated ABCEVA method. Once implemented, the integrated method can be used as an engineering management tool to protect company managers from making short-term decisions based on profit alone that may destroy economic value over the long term. The proposed integrated method by itself will not make improvements in the business process, but rather will provide management with information that can direct improvement efforts in which management should be committed to make these necessary improvement steps.

\section{REFERENCES}

1. Cooper, R. and Kaplan, R.S. (1988), Measure Cost Right: Make The Right Decisions, Harvard Business Review, pp. 96-102. (September-October 1988)

2. Drury, C. (1989), Activity-based costing, Management Accounting, pp. 60-66. (September 1989)

3. Bailey, J. (1991), Implementation of ABC Systems by UK Companies, Management Accounting, pp. 30-32. (February 1991)

4. Cooper, R. and Kaplan, R.S.(1992), Activity-Based Systems; Measuring the Costs of Resource Usage, Accounting Horizon, pp. 1-13. (September 1992)

5. Dhavale, D. (1992), Activity-Based Costing in Cellular Manufacturing Systems, Industrial Engineering, pp. 44-46. (February 1992)

6. Sohal, S.A. and Chung, W.C. (1998), Activity-Based Costing in Manufacturing: Two Case Studies on Implementation, Integrated Manufacturing Systems, vol. 9, no. 3, pp. 137-147.

7. Shrieves, R.E. and Wachowicz, J.M. (2001), Free Cash Flow (FCF), Economic Value Added (EVA), and Net Present Value (NPV): A reconciliation of Variations of Discounted-Cash-Flow (DCF) Valuation, The Engineering Economist, vol. 46, no. 1, pp. 3352.

8. Hubbell, W.W. (1996), Combining Economic Value Added and Activity-Based Management, Journal of Cost Management, pp. 18-29. (Spring 1996).

9. Cooper, R. and Slagmulder, R. (1999), Integrating Activity-Based Costing and Economic Value Added, Management Accounting, pp. 16-17. (January 1999) 